\title{
研究課題別事後評価結果
}

\section{1.研究課題名 ゲノム安定保持を保証する細胞核構造の解明」}

2. 研究代表者名及び主たる研究参加者名 研究機関名 職名は研究参加期間終了時点) 研究代表者 平岡 泰 情報通信研究機構 グループリーダー)

\section{3.研究内容及び成果 :}

平岡グループは、体細胞分裂時および減数分裂時の細胞核染色体構造の挙動の解析を目的 として一連の研究を行った。体細胞分裂時の染色体および細胞核構造の変化に関する研究には、 主として全DNA 配列が最近明らかになったヒ泪田胞を用い、減数分裂時の染色体構造の変化に関 する研究は、体細胞分裂時から減数分裂時に移行する過程において染色体構造が劇的に変化 する分裂酵母を用いて行った。これらの染色体および細胞核構造の挙動の解析には、蛍光顕微 鏡によるイメージングと分子生物学的手法を併用したが、特に新たに細胞内タンパク質の動的挙 動や相互作用の解析を可能にする蛍光顕微鏡による生細胞イメージンク技術を開発した。同時に、 分裂酵母の蛍光タンパク質のライブラリーや DNA マイクロアレイなども作製した。以下に平岡グル ープの主な研究業績を列記する。

(1)蛍光顕微鏡を基盤とした生細胞イメージンク技術の開発をし、生細胞を最大 4 種類の生体 分子を併行で染め分け、光の分子の挙動を数日間にわたつて追跡することを可能にした。また、 FRET 法を用いてタンパク質の細胞構造内での移動速度を計測し、タンパク質分子間の相互作用 を画像化することにも成功した。平岡グループの生細胞蛍光イメージンク技術は、世界的に見て 最高のレベルにあり多くの細胞内タンパク質の挙動を解析したが、具体的には核膜の構成タンパ ク質であるラジBレセプターや emerin などを蛍光ラベルし、細胞核が崩壊し再構築する過程を追 跡した。これによって、細胞核の再構築過程において、これらタンパク質と染色体タンパク質との相 互作用か明らかになつた。(2)主として分裂酵母を用い、体細胞分裂時、減数分裂時における細 胞核構造の変化に関する詳細な解析を行った。まず、分裂酵母の減数分裂時においてセント口メ アがSPBから離れ、代わりにテロメアがSPB の近くにクラスターを形成し、このクラスターを先頭に核 が往復することか明らかになった。こようなテロメアクラスターは、分裂酵母のみならず高等動植 物においても見られ、真核生物の減数分裂時における普遍的な現象であることか実証された。さら に、平岡グループは体細胞分裂時にセントロメアを SPB に留める分子や減数分裂時にテロメアを SPB に留める分子を同定した。これらの分子の同定により セントロメアとテロメアの配置を制御する 機構について重要な示唆が得られた。これらのタンパク質のうちで高等動物と共通なタンパク質に ついて、光の役割をヒ㥉養細胞および卜培養細胞において解析した。さらに、上述した減数分裂 時におけるテロメア先導の核運動の仕組みを解析するために分裂酵母から突然変異株を取得し、 兴の変異株における核内構造の変化を生細胞観察した。この結果、核の運動は微小管によって起 こること、さらに相同染色体の対合を促進することが判明した。さらに、セントロメアとテロメアと核内 配置の逆転にMAP キナーゼか関与していることを明らかにしたが、これはMAPキナーゼが減数分 裂時の染色体分離の重要な制御分子であることを示している。平岡グループは最近セントロメアを SPB に留めるタンパク質 Nuf2 を同定したが、本タンパク質は高等動植物にも共通に見られることか ら、真核生物における減数分裂時において共通な一般的役割を果たしていると思われる。一方、 テロメアをSPB に留めるタンパク質としてRap1タンパク質複合体を同定した。本タンパク質もヒ怆も 見られることから真核生物における共通な役割力想定される。さらに、平岡グループは DNA マイク ロアレイを用い、分裂酵母において接合フェロモン制御下に発現する遺伝子のうちからテロメアクラ スター形成に関わる新規遺伝子も同定した。(3)減数分裂時における相同染色体に対合と組換え 分離の過程を生きたままて観察する系を確立した。この目的で分裂酵母の染色体の特定領域を蛍 光染色し、この標識された染色体領域を生きた細胞で追跡できることを可能にした。更に、この方 法と突然変異株での解析と組み合わせることによりテロメアクラスターや核の往復運動、組換えが 相同染色体の対合にどのように働くかを明らかにした。 


\section{4.事後評価結果}

4-1.外部発表(論文、口頭発表等)、特許、研究を通じての新たな知見の取得等の研究成果の 状況

事後評価において、平岡グループの生細胞蛍光イメージング法の開発、これを用いたヒ㤋裂 酵母の核内の諸構造の変化の蛋白レベルで解析については評価者ほぼ全員が高い評価を与え た。また、吉田グループと共同で分裂酵母の GFP ライブラリーを作製したことも評価した。一方、平 岡グループの研究テーマが一時吉田グループのテーマとオーバーラップする時期があり これに ついて产の後補正がなされたが、CREST のプロジェクトにおける研究の独自性と協力関係を成果 としてどの樣に評価するかとい点で問題を残したことは否めない。補正後の平岡グループの研究 はレベルが高く、評価者一同はこれに高い評価を与えた。

\section{4-2.成果の戦略目標 科学技術への貢献}

平岡グループの研究成果は、体細胞分裂や減数分裂時における細胞内の蛋白質の挙動を新し い切り口により 且つ網羅的に解析する技術を開発したことであり 今後樣々な方面において钅の 有用性か認められることであろう。特に、生殖医療において問題になっている生殖細胞の形成異 常なと樣々な生殖分裂や体細胞分裂の異常に由来する疾患の治療において、乥れらのメカニズ ムを理解するのに役立つことが期待される。一方、平岡グループは主として分裂酵母を用いて解 析を行ったが、分裂酵母は出芽酵母と並んで単細胞真核生物のモデルであり この点において平 岡グループが作った分裂酵母 GFP 融合ライブラリーは極めて有用であり 単細胞真核生物の研究 における我が国の優位を引き続き保つ上で重要なリノースとなるであろう。た平岡グループが 開発した生きた細胞内の分子のイメージンク技術は、複雑な細胞内の反応を視覚化するために生 体内反応を容易に理解されることから、生物学の啓蒙化において有効な役割を果たすことか期待 される。

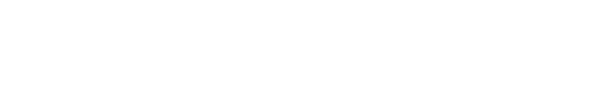

